\title{
The ground stone industry at Pericei-Keller tag. A secondary production centre?
}

\author{
Mihai Dunca 1, Sanda Băcueț Crişan 2 \\ 1 independent researcher \\ mihaidunca2013@gmail.com \\ 2 County Museum of History and Art, Zalău, RO \\ sandabacuet2001@yahoo.ro
}

\begin{abstract}
This article analyses ground stone discoveries from the late Neolithic site of Pericei in northwest Romania, in the Simleu Depression. The combined characteristics of chisels and adzes in the working process are discussed, along with their context, especially those processes connected to stone working: the cultural layer, dwellings and pebble agglomerations. We conclude that Pericei was a centre for the production of stone chisels, and it appeared to supply demand that until then had been satisfied by the Suplac/Port site, which continued to produce ground stone tools for a longer period.
\end{abstract}

KEY WORDS - chisels; adzes; stone-working techniques; operational sequence; polished stone

\section{Proizvodnja glajenih kamnitih orodij na najdišču Pericei-Keller tag. Sekundarni center proizvodnje?}

\begin{abstract}
IZVLEČEK - V članku analiziramo glajena orodja najdena na poznoneolitskem najdišči Pericei $v$ severozahodni Romuniji v globeli Simleu. Razpravljamo o skupnih značilnostih in kontekstih dlet in tesel v delovnih procesih, predvsem tistih, ki so povezani z obdelavo kamna: kulturna plast, bivališče in skupki prodnikov. Sklepamo, da predstavlja Pericei center za proizvodnjo kamnitih dlet, ki je oskrboval območja, ki so bila do takrat oskrbovana iz najdišča Suplac/Port, kjer so proizvajali glajena kamnita orodja v daljšem časovnem obdobju.
\end{abstract}

KLJUČNE BESEDE - dleta; tesla; tehnike obdelave kamna; operacijska sekvenca; poliran kamen

\section{Introduction}

The late Neolithic period relates to the most productive ground stone processing in Europe. It is a period in which some settlements present a large number of ground tools, especially edge tools worked for more than household needs, and we can mention here the sites at Rivannazano in northern Italy (D'Amico, Starnini 2011; 2012; Pétrequin et al. 2012) and Makriyalos in Greece (Tsoraki 2007; 2011). In Romania, the highest frequency and number are encountered at the Suplac/Porţ-Corău site
(Bihor and Sălaj county, which is why it has two names), located in the northwest of the country, in the Simleu Depression. The discovery of 500 polished tools along with worked raw material at Suplacu de Barcău led Doina Ignat to the conclusion that ground stone processing was oriented to exchange (Ignat 1998.32-33). Later research at Port (the part of the site at Sălaj; Băcueț Crişan 2008; Băcueț Crişan et al. 2011; 2012; 2013) over larger areas led to the discovery of 1641 pieces and raw material in diffe- 
rent working stages (Dunca 2015; 2016b).

The Pericei site is also in the Simleu Depression (Fig. 1). Based on the cultural traits, mainly the pottery style, it has been assigned to the ClujCheile Turzii-Lumea Nouă-Iclod-Suplac (abb. CCTLNIS) cultural complex (Băcueț Crișan 2007; 2008) which includes several groups defined by one key site. We have two cultural and chronological assignments within this complex: as part of the Cluj group, and anterior to the Suplac group (Lazarovici, Lazarovici 2006.413) or as contemporary with the Suplac II phase, defined on the basis of the stratigraphy and pottery of the second layer from Suplac/Porț (Băcueț Crişan 2008.52-53; 2007.70-72), being a site with Suplac type pottery (Băcuet $\mathrm{Cri}$ san, Pop 2014.35-36; Glascock et al. 2016.77-78). The second assignment will be used in this paper. We have no absolute, radiocarbon data from Pericei or Suplac/Porţ. In a relative chronology, the evolu-

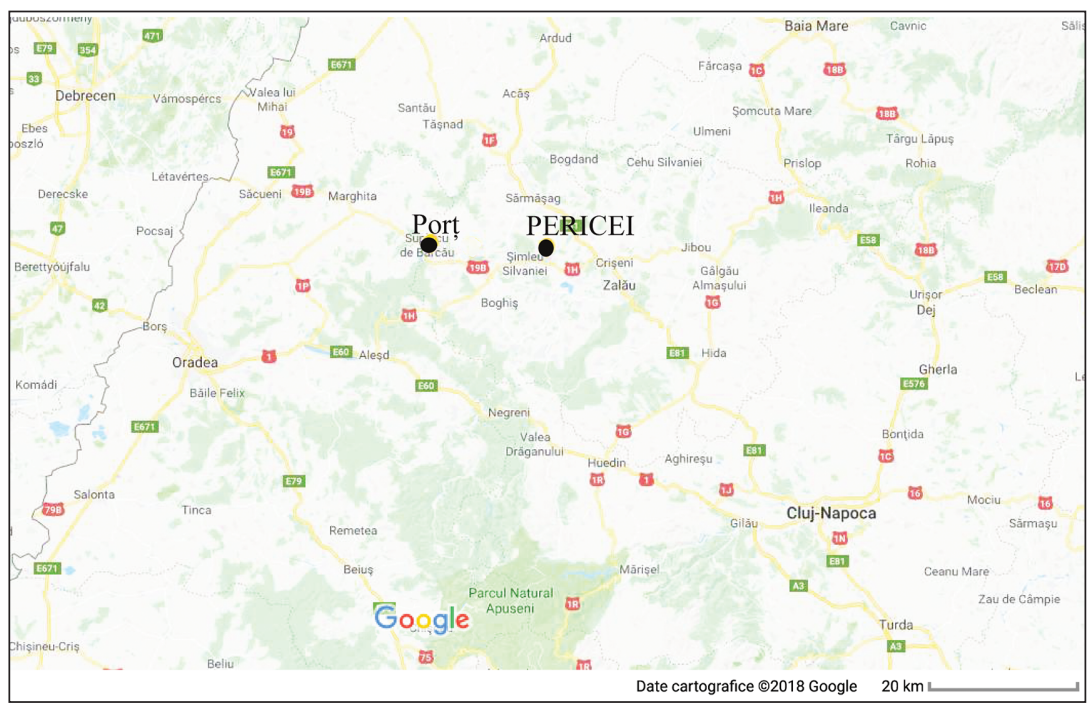

Fig. 1. Maps showing sites Pericei and Porţ.

tion of Suplac I phase is related to the interval Tisa I-I/II-Herpály I-II- Vinča C1-C2 (Băcueț Crişan 2013. 17), so the Pericei site must be later, but still in the Vinča $C$ interval, given the incised Turdaş pottery type discovered there.

Two layers had late Neolithic material, the upper one with a constant spread, and the lower one identified only at the centre of the site (Băcuet Crişan

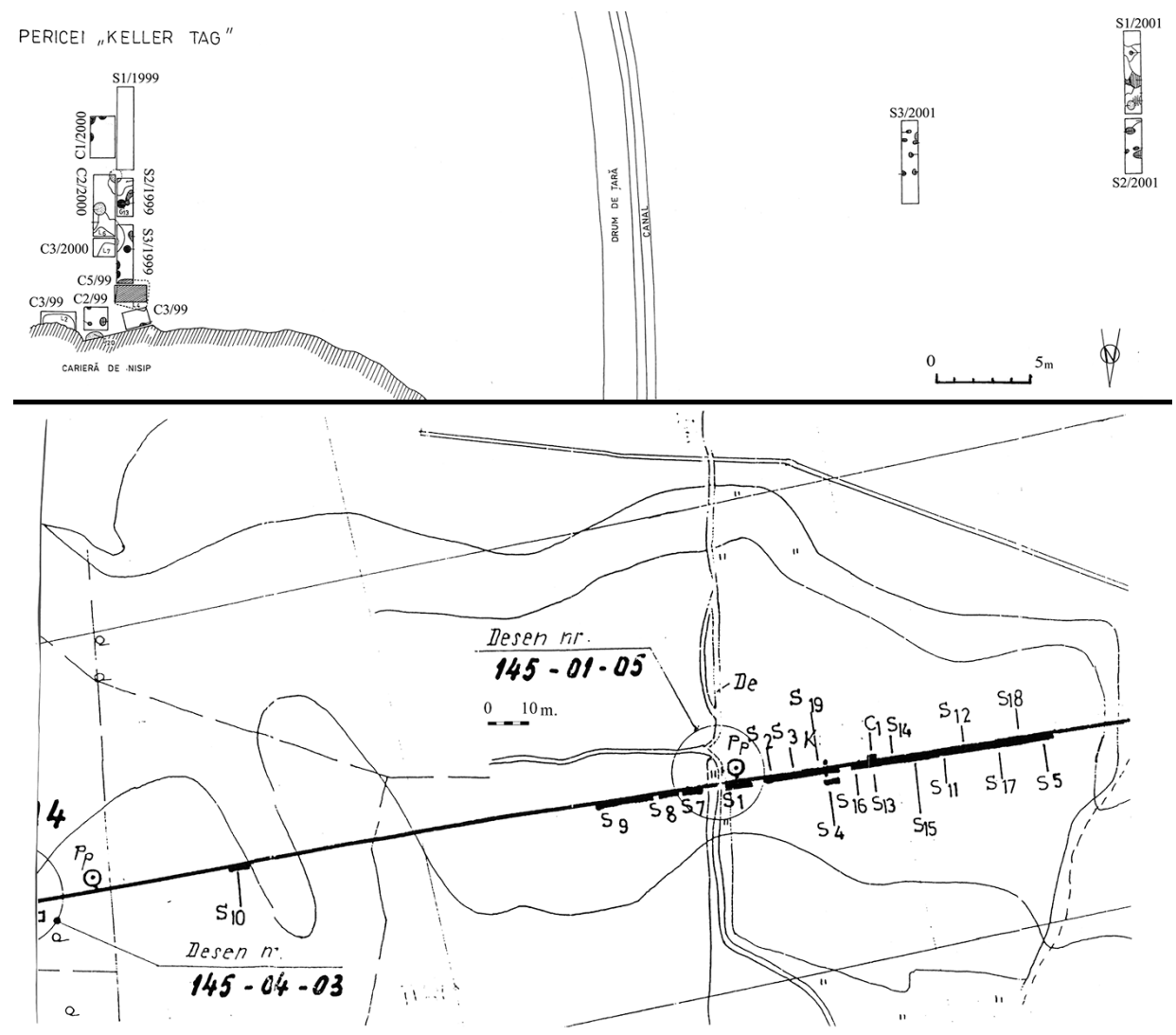

Fig. 2. Plans of the surfaces investigated at Pericei. 
2008.28-29). The ground stone material was found in the following 15 trenches excavated between 1999 and 2004: C1/1999, C2/2000 (8 x 2.5m), C3/2000 (2 x 2.50m) (Fig. 2.1; Băcuet Crișan 2008.27-28), C1/2004 (5 x 3m), S1/2004 (24 x 2m), S4/2004 (25 x $2 \mathrm{~m}$ ), S5/2004 (28 x 2m), S11/2004 (33 x 2m), S13/ 2004 (10 x 2m), S14/2004 (27,5 x 2m), S15/2004 (32.7 x 2m), S16/2004 (17 x 2m), S17/2004 (55 x 2m), S19/2004 (46 x 2m) (Fig. 2.2; Matei et al. 2000. 259-262).

\section{Raw material}

There are no petrographic analyses for Pericei, but considering the proximity of the Suplac/Port site, we can assume the same lithic sources, the Plopis Mountains, with alluvial exploitation (from the Barcău Valley for Suplac/Port;; Ignat 1998.10; Lazăr et al. 2007. 34). In the Pericei case, rocks could have been collected from the valley of the River Crasna. At Suplac/Porţ, rocks with a high degree of hardness were used: e.g., amphibolite, quartzite, rhyolite, dacite, porphyry, as well as other rocks such as paragneis, chlorite shale, amphibolite-chlorite shale, and feldspar sandstone, and only rarely softer rocks such as limestone marl, mudstone, and clay sandstone ( $I g$ nat 1998.33). We could not say for sure that all these rocks were used at Pericei, but most of them probably were, considering the resemblance between the lithic material of both sites. Unworked stone was found at Pericei in the form of five pebble agglomerations (Fig. 3): C18/S11 (representing two close agglomerations), $\mathrm{C} 30 / \mathrm{S} 13, \mathrm{C} 33 / \mathrm{S} 11$, and C69/S14. Compared to the Suplac II phase from Porţ, where 11 such agglomerations were discovered (Dunca 20166.90, Pl. 1), Pericei also has the same frequency of these structures, if not higher. Traces of burning were found next to the $\mathrm{C} 30 / \mathrm{S} 13$ agglomeration. We give the same explanation as in the case of Port for these features, as places for working raw material, either by thermal shock or by percussion (Dunca 2016b.84). Ethno-archaeological observations in New Guinea have shown that fire can be used to break stone and obtain fragments to be processed afterwards (Pétrequin et al. 2006. 421-422; Pétrequin, Pétrequin 2000.21; Jeudi et al. 1995.253).

\section{Classification of the ground stone sample}

The total of 73 ground stone sample is comprised of: cores $(4 \%)$, preforms $(8 \%)$, waste $(3 \%)$, chisels $(41 \%)$, axes $(5 \%)$, axe-chisels (1\%), adzes (11\%), hammers (percutors) (1\%), sandstone slabs (1\%), millstones

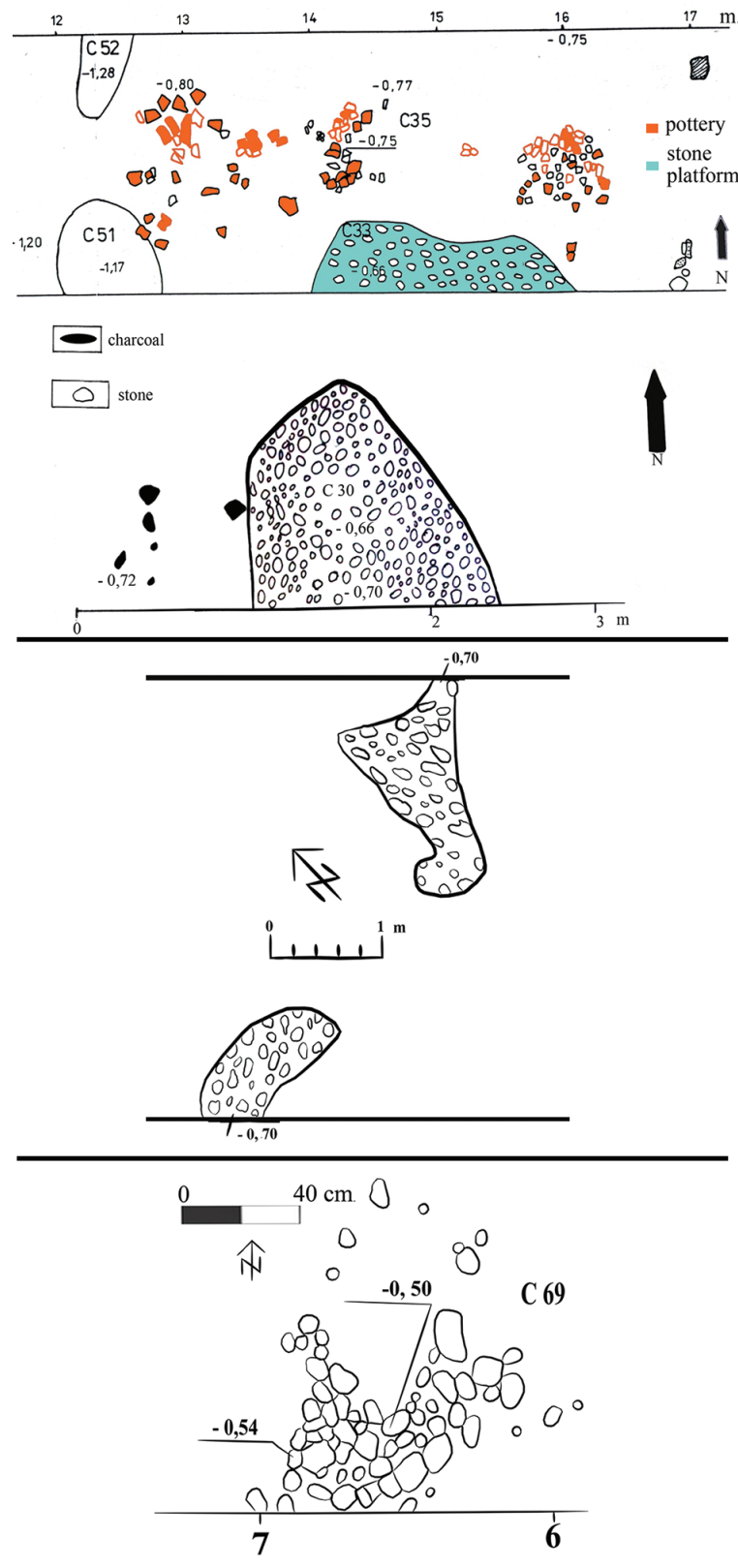

Fig. 3. Pebble agglomerations from Pericei.

(7\%), grinders (9\%), and stone fragments (10\%). For typology, we used the typological classification made for Port (Dunca 2016a) and related these results to the phases of working observed on the lithic material at the same site (Dunca 2015). For a better understanding of the present analysis, we resumed the main ideas of those two studies. The most difficult problem was separating the main categories of edge tools - chisels, axes and adzes - but as we had a larger sample at Porţ, this was possible by comparing and selecting some general traits. Chisels are usually shorter (approx. $7 \mathrm{~cm}$ ), thinner and flat (at least one face). Axes are the largest items, being more than $10 \mathrm{~cm}$ long and 3 to $4 \mathrm{~cm}$ wide, and have a more prominent cutting edge than chisels. Adzes 
are asymmetrical as a result of the cutting edge being sharpened mostly from one side. Their proportions are similar to chisels in most cases. Each category was divided into types and variants based on shape respectively, the longer profile (considered from the base of the cutting edge) or reversing the two characteristics if the profile was more important in relation to the use of the tool. These were the criteria used by Ignat for the tools from Suplacu de Barcău (Ignat 1998.35-36), but in a different and more complicated combination.

Several working stages can be established. The contouring of the cutting edge was considered the limit between the worked raw material and pieces in the working process. Raw material was divided into cores by methods that we present in the sample analysis. This was followed by the reduction or splitting of the cores into fragments similar to the tools that were being fashioned (chisels, axes, adzes). We classified these fragments as preforms. They became tools after polishing, often combined with pecking. The two working stages, initial and advanced, were separated based mainly on the symmetry of the shape compared with the finished product. There are differences between pieces included in the same working stage, both at Port and Pericei; the latter will be detailed in the following parts of the paper.

\section{Cores}

We have two simple cores (Fig. 4.1-2; Fig. 12.1-2) the first being a pebble fragment, and the second a whole stone with a fissure that could be connected to the use of thermal shock, according to experi-

\begin{tabular}{|lccc|}
\hline & total & sawing and pecking & pecking \\
\hline Preform & 2 & 2 & \\
\hline Chisel preform & 3 & & 3 \\
\hline Ax-chisel preform & 1 & 1 \\
\hline
\end{tabular}

Tab. 1. Characteristics of the preforms.

mental archaeology (Pétrequin et al. 2012.263, Fig. б). The third (Fig. 4.3; Fig. 12.3) is from the category of cores with working traces (which relate to actions after the breaking of the raw material), presenting saw marks on a small surface.

\section{Preforms}

Of the six samples, we were able to determine pieces with dimensions close to the chisels (Fig. 4.4-6; Fig. 12.4-6) and a fragment similar to the axe-chisels (Fig. 4.7; Fig. 12.9); the remainder (Fig. 4.8-9; Fig. 12.7-8) do not fit clearly into a category of stone tools. The combining of processing techniques is illustrated in Table 1.

Two of the preforms display sawing marks either on a face or contour, as well as pecking marks on the contour. Sawing was required to split the cores, while pecking followed to achieve the desired shape, combined with brief polishing. The preforms that match a tool category only illustrate the pecking applied to the contour, probably after detachment from the core, in which case the saw marks were obliterated by subsequent operations.

Two fragments of waste (Fig. 4.10-11; Fig. 12.1011) were found, both with pecking marks.
Fig. 4. Raw material: 1 simple core (dwelling C1/S1); 2 core with fissure (layer); 3 core with sawing marks (layer); 4-5 chisel preforms (layer); 6 chisel preforms (dwelling C68/S14); 7 axe-chisel (layer); 8-9 undefined preforms (layer); 10 waste with pecking marks (layer); 11 waste with pecking marks (dwelling C68/S14).
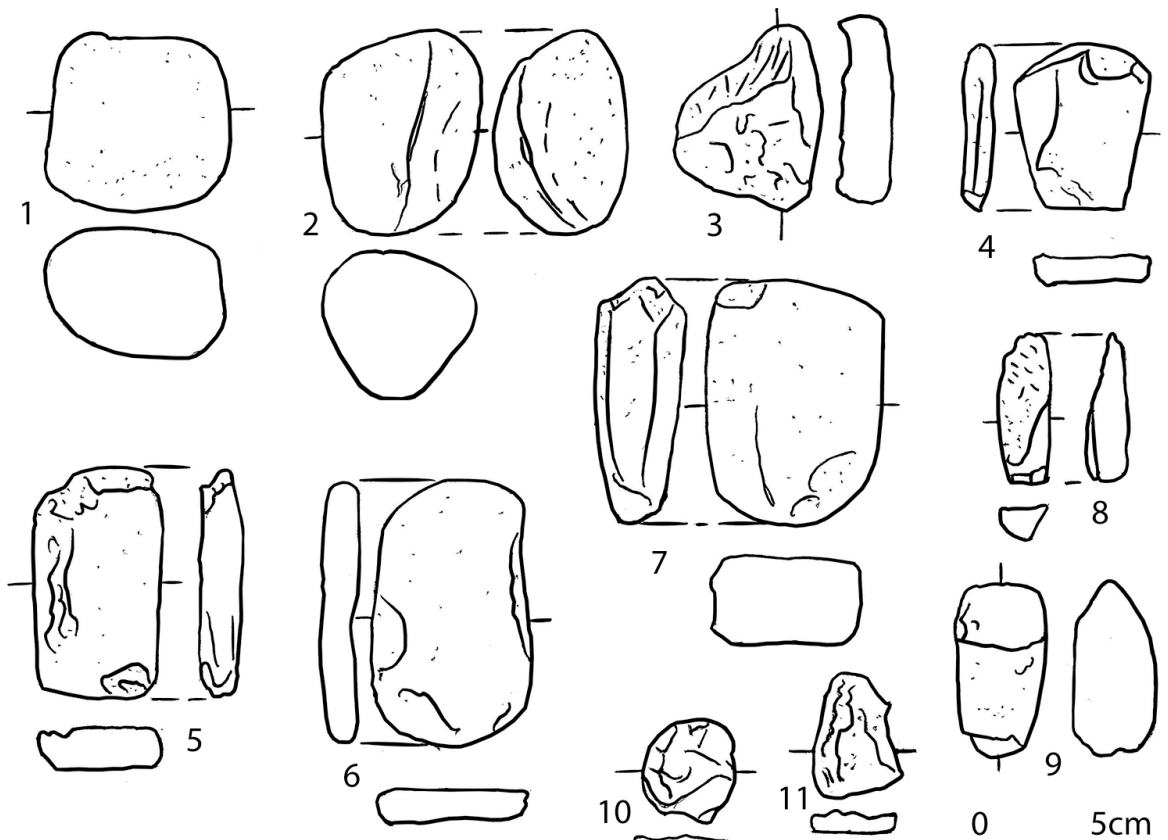

4

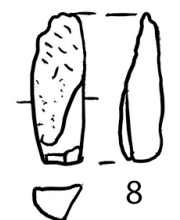

7
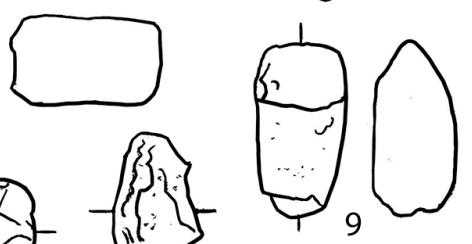

10
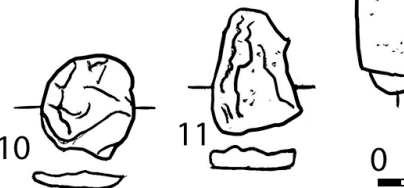

$5 \mathrm{~cm}$ 


\section{Chisels}

Typologically, chisels are divided (Fig. 5) into D1 rectangular, D2 elongated, D3 trapezoidal, and D4 oval. The only finished pieces are trapezoidal - variants D3a (with a rectangular profile; Fig. 8.1; Fig. 13.1) and $\mathrm{D} 3 \mathrm{~d}$ (with an oblique profile; Fig. 8.2; Fig. 13.2) - and oval, variant $D 4 c$ (with a rounded profile; Fig. 8.3; Fig. 13.3), which means just $11 \%$ of the total, a smaller proportion of finished chisels than is present at Port, where the proportion varies between $8 \%$ and $30 \%$, according to type. Taking into account the slightly higher proportion of chisels at Pericei than at Port, we can assume they were worked more frequently for exchange than for internal needs. Samples framed within the typology can be divided almost equally between the initial and advanced stages of working, which indicates a higher proportion of the initial stage than at Port. Regarding the quantities, the situation is analogous to the Suplac III phase at Porț (Dunca 2016a.Tab. 1): chisels of $\mathrm{D} 3$ type predominate, followed by the $\mathrm{D} 1$ type, with the fewest being the $\mathrm{D} 2$ type.

The chisels assigned to the advanced stage of working (Fig. 8.4-9; Fig. 13.4-9) were grouped according to the sharpening of the edge and the degree of polishing on the surface, adding secondary characteristics (Fig. 6).

An advance in working over the rest is illustrated by artefacts of category A with a sharp edge. Those from category B have only a contoured edge, which, along with the advanced polishing, represents the general characteristic of this working stage. Pecking marks appear on the contour, so they must be connected to the achievement of form. The symmetrical contour of some chisels indicates a focus on obtaining the desired shape first, while concentrating on smoothing the faces and sharpening the edge afterwards.

Initial stage of working (Figs. 7; 8.10-13; 9. 1-8; 14; 15.1-2)

Pieces included in categories A and B present a feature, a slightly contoured edge, often encountered in chisels in initial processing, meaning a thicker one compared to a contoured edge that is thin and needs only a little grinding to become functional. Pecking marks appear often, not only on the margins but also on the faces of the chisels. The unlevelled faces could be the result of polishing after pecking. Saw marks are sometimes visible. They could be the remains of the preform stage, but more probably, since the pieces had undergone enough changes, it could be a new sawing phase, having the same role as pecking, i.e. the removal of excess stone in a faster way than by polishing alone. The difference between superficial and advanced polishing (B category) can be explained by the application of less pecking, or perhaps none at all, and more polishing for surface adjustment.

\section{Axes}

Only one complete example of this category was found, assigned to the T2a type (elongated, with a

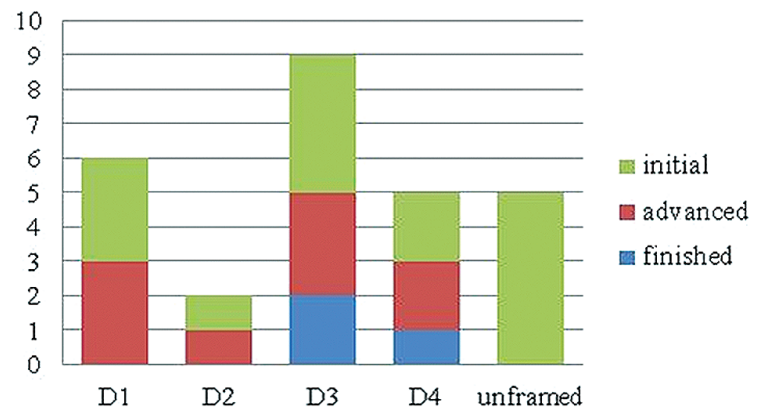

Fig. 5. Division of the chisels by type and working stage.

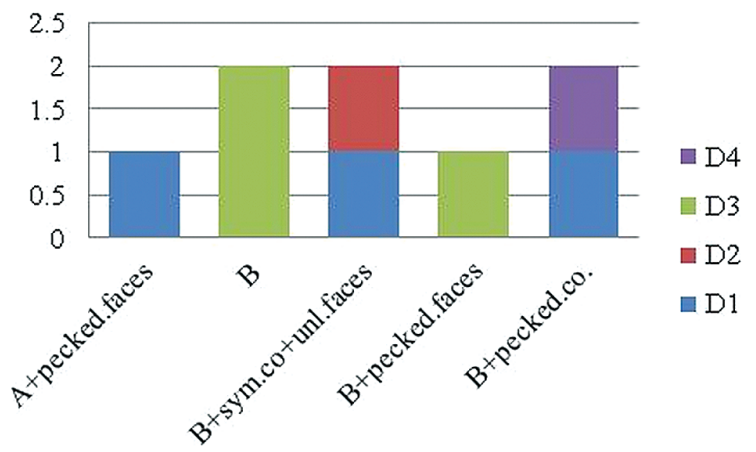

Fig. 6. Combined characteristics of the chisels in advanced working stage. A sharp edge and advanced polishing (Pl. 5.4); B contoured edge and advanced polishing (Pl. 5.5-9) (sym. symmetrical; co. contour; unl. unlevelled).

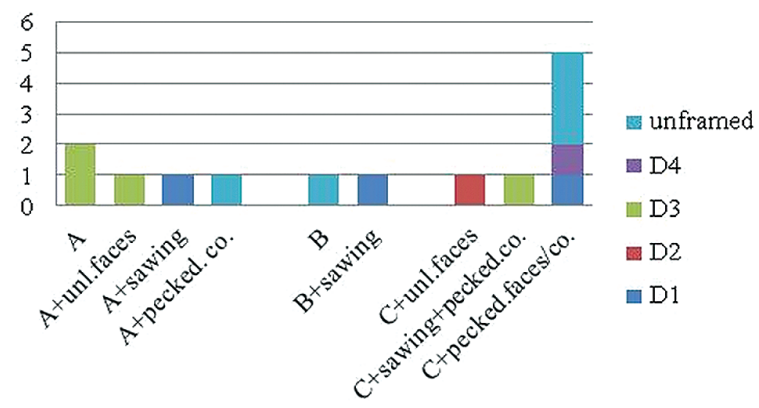

Fig. 7. Combined characteristics of the chisels in initial working stage. A slightly contoured edge and superficial polishing (Pl. 5.10-13); B slightly contoured edge and advanced polishing (Pl. 6.12); C contoured edge and superficial polishing (Pl. 6.3-8) (co. contour; unl. unlevelled). 
Fig. 8. Finished chisels (1-3), chisels in advanced working stages (4-9) and chisels in initial working stages (10-13). 1 type D3a (dwelling); 2 type D3d (layer); 3 type D4c (layer); 4 category $A$, type D1 (layer); 5-6 category B, type D1 (layer); 7 category $B$, type D2 (layer); 8 category B, type D3 (dwelling C35/S11); 9 category B, type D3 (dwelling C35/ S11); 10-11 category A, type D3 (layer); 12 category A, type D1 (layer); 13 undefined (ditch C106/S7).

rectangular profile; Fig. 9.9; Fig. 15.3). Another three fragments, one of which one has perforations, can be added, but they cannot be assigned to a type. We mention here an axe-chisel of TD2 type (trapezoidal form; Fig. 9.10, Fig. 15.4). The term 'axe-chisel' does not necessarily denote a mixed tool, but mixed features. They have the appearance and relative proportions of the chisels, but the massiveness of the axes (Dunca 2016a. 90).

\section{Adzes}

The same types defined at Port were also identified at Pericei (Fig. 10), with some differences in variants. The Te1 type (trapezoidal type) includes a piece with a rectangular profile (type Te1d; Fig. 9. 12; Fig. 15.5). The second type, Te2 (with an elongat-
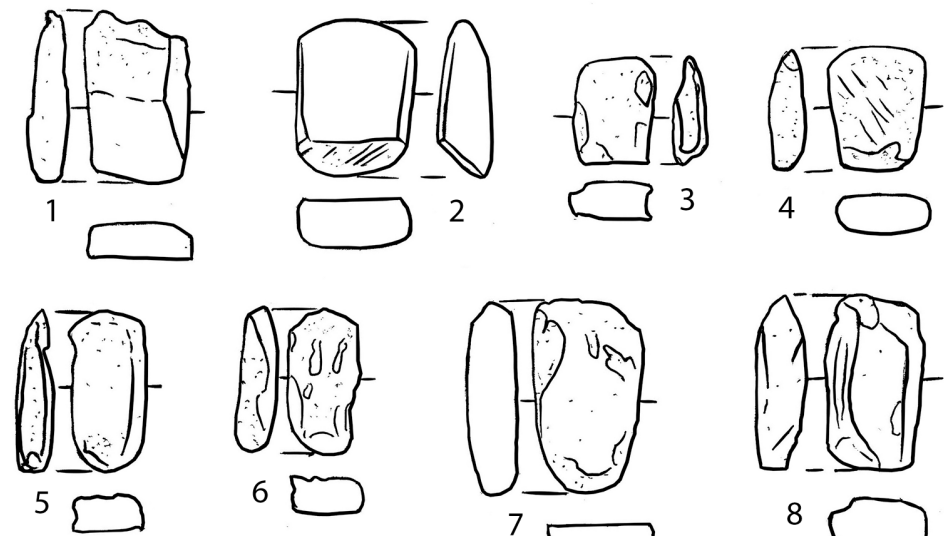

6
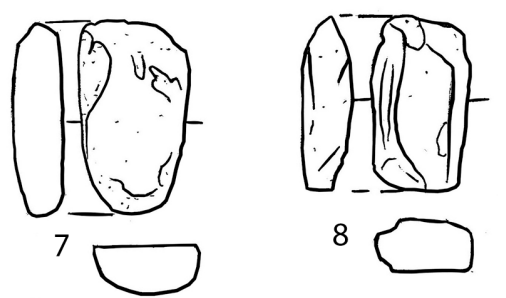

8
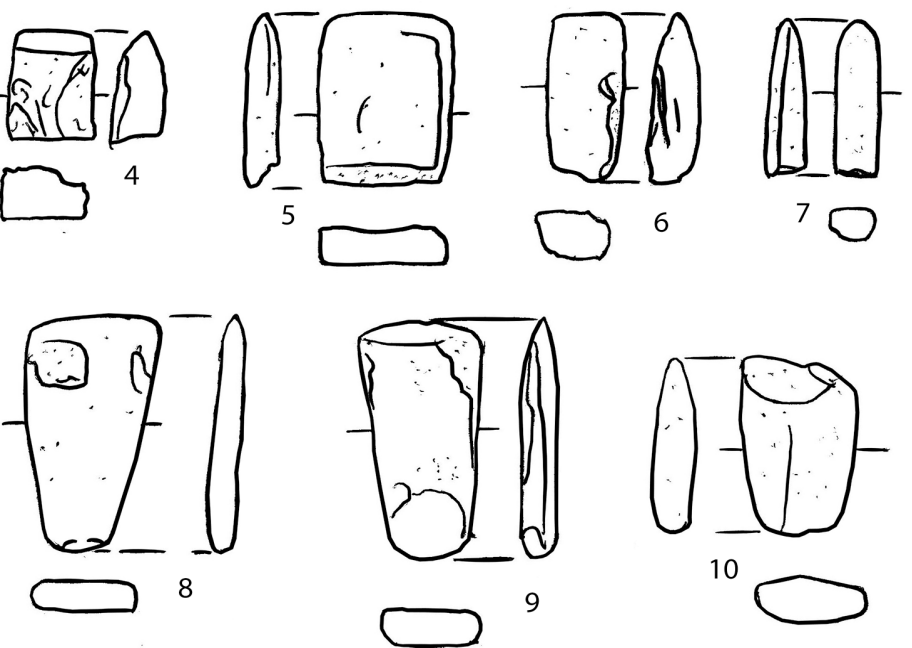

10
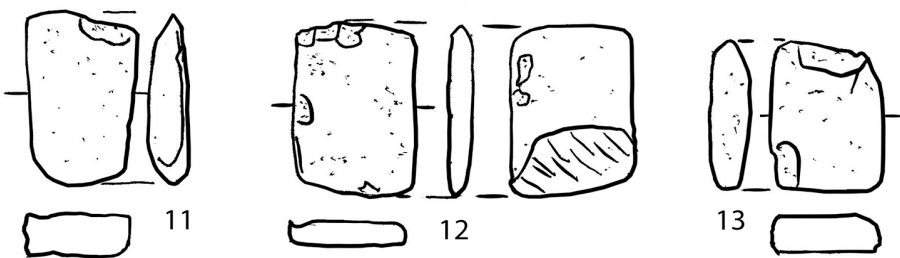

ed form) is divided into sub-types Te2a with a rectangular profile (Fig. 9.11; Fig. 15.6), and sub-type Te2b with an oblique profile (Fig. 11.1; Fig. 15.7). The oval shaped $\mathrm{Te} 3$ type has one variant $\mathrm{Te} 3 \mathrm{~b}$ with a rectangular profile (Fig. 11.5-6; Fig. 15.8-9) not found at Porţ. For the rectangular Te4 type, we have one variant Te4a with a rectangular profile (Fig. 11.2; Fig. 15.10). Adzes were much more numerous at Pericei than at Ports. They comprise 11\%

Fig. 9. Chisels in initial working stages (1-8), axes (9-10) and adzes (11-12). 1 category $B$, undefined (layer); 2 category B, type D1 (pit C74/S17); 3 category C, type D1 (layer); 4 category C, type D3 (layer); 5 category C, type D4 (layer); 6 category $C$, undefined (layer); 7 category C, undefined (pebble agglomeration C30/S13); 8 category $C$, undefined (dwelling C48/S13); 9 axe, type T2a (layer); 10 axe-chisel, type TD2 (layer); 11 adze, type Te2a (pebble agglomeration C33/S17); 12 adze, type Te1d (grave C21/S11). 


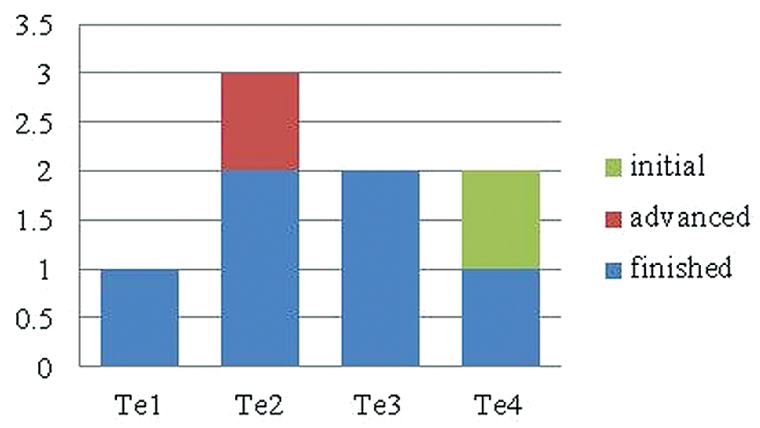

Fig. 10. Division of the adzes by type and working stages.

of the total lithic sample in the first case, and only $2 \%$ in the second. In terms of finished pieces, adzes constitute the main category of wood-working tool at Pericei, while at Port these finds are only in third place, with axes being in second place (Dunca $2016 \mathrm{~b}$. Tab. 1-3). Most of them are visibly worn, especially the edges.

Only two adzes were left in the working process. Based on the asymmetry, the unlevelled faces and superficial polishing, the Te4 adze (Fig. 11.3; Fig. 15.2) can be assigned to the initial stage. The advanced stage of working includes a Te2 adze (Fig. 11.4; Fig. 16.1) with advanced polishing. Both of
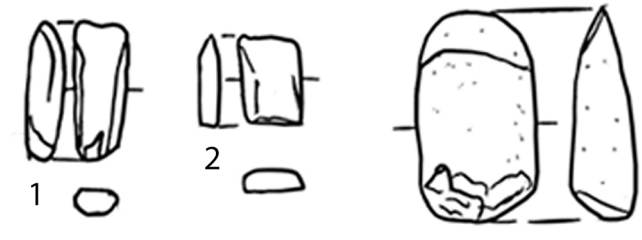

3

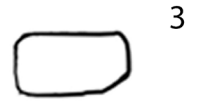

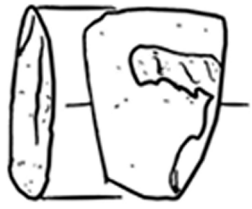

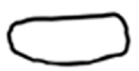

6
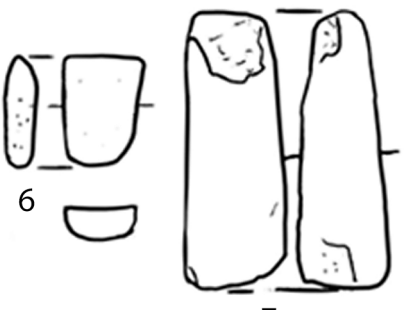

7
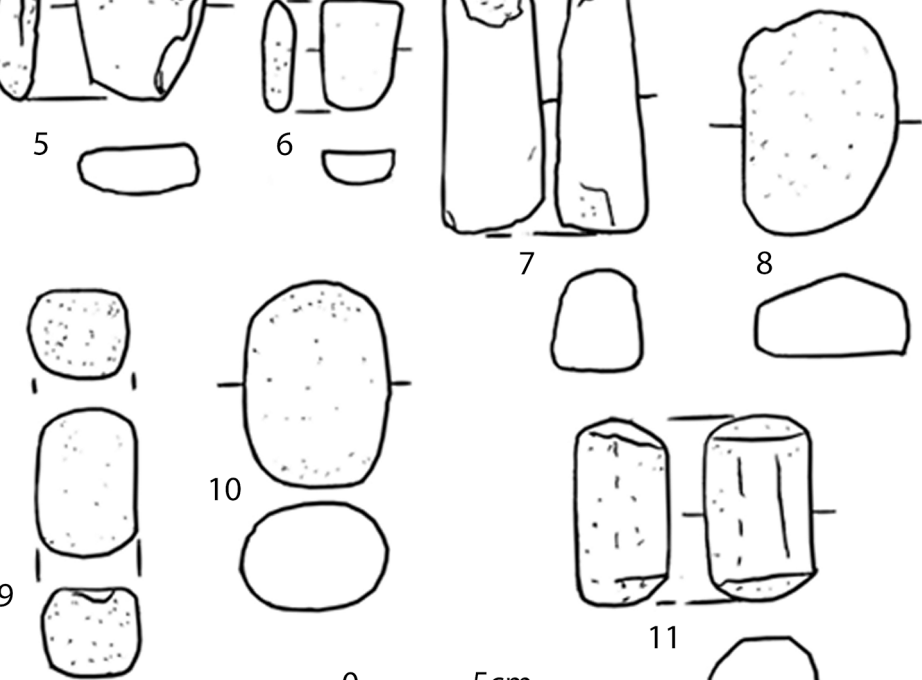

8
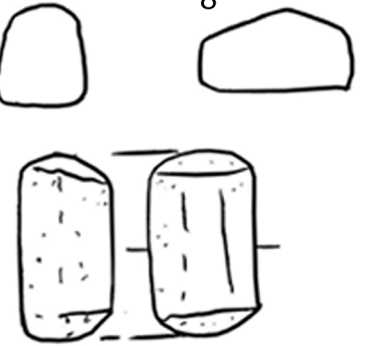

11

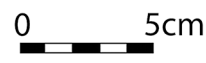

(1)

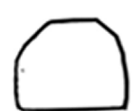

them have a contoured edge and pecking marks, so we can assume similar working methods as in the case of the chisels, although we can make no observations about the shaping of the adzes.

\section{Tools for stone working}

Just two pieces of this category were found, a percutor (Fig. 11.7; Fig. 16.3) and a sandstone slab (Fig. 11.8; Fig. 16.4). The percutor would match the long P3 type from Port, but it lacks the perforation. The narrow end makes it suitable for pecking. The sandstone slab is rather small; it could have been held in the hand during polishing.

\section{Tools for grinding}

Apart from seven grinder fragments (Вӑcuet Crişan 2008.38), the other tools in this category are millstones of the elongated Z2 type (Fig. 11.9-11; Fig. 16.5-7). More were found than at Port, and considering the low representation of percutors, we may conclude that the millstones were also used for pecking, or at least some of them.

\section{Context analysis}

The majority of ground stone finds (59\%) come from the upper habitation layer. The other $29 \%$ were

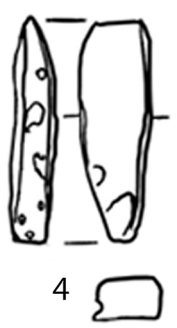
found in dwellings, while $12 \%$ were discovered in other contexts, such as pits, graves, ditches, and the pebble agglomerations mentioned at the beginning of this article. We will first discuss the samples that came from contexts related to stone working.

Following Table 2, we can observe that no category or even frequent type is missing from the layer. The same can be said for all the working stages, starting with cores and ending with finished tools; hence we conclude that the whole operational chain related to

Fig. 11. Adzes (1-6), percutor (7), sandstone slab (8) and millstones (9-11). 1 adze type Te2b (layer); 2 adze type Te4a (layer); 3 adze in initial working stage, type Te4 (pit C29/ S13); 4 adze in advanced working stage, type Te2 (dwelling C49a/S15); 5 adze type Tezb (layer); 6 adze type Te3b (dwelling L3); 7 percutor type $P 3 b$ (layer); 8 sandstone slab (layer); 9-11 millstones type Z2 (layer). 
production could have taken place outside the houses, in open areas. The initial working stage is predominant, and in terms of typology, the D3 type of chisel predominates. The frequency is lower than at Porț, where no more than $1 \mathrm{~m}^{2}$ of ground free of archaeological features lacked pieces of stone or worked raw material (Dunca 2016b.84).

Nine of the 16 dwellings contained ground stone items. Chisels are the most common, but in the advanced working stage. Except for trench $\mathrm{C} 1 / \mathrm{S} 1$ where a core was found, and trench C68/S14 from which a preform and a discard came, nothing indicates the possibility of ground stone tools being made entirely inside houses. More probably, finishing was done inside the dwellings after the first part of the process took place outside. A similar division was concluded for the pieces from Hauterive Champréveyres in Switzerland (Joye 2012.42) due to a smaller amount of waste produced in later working stages.

Ground stone industry discoveries are rarely presented by context or even mention one. We have selected a few Eneolithic sites where such information exists in order to determine the role of the items from the Pericei dwellings. At Carcaliu (Tulcea county), a settlement of the Gumelnitsa culture, half of the dwellings revealed a ground stone inventory, from one to 16 pieces, but grinders and millstones predominated in all of them; edge tools amounted to no more than three per dwelling (Micu et al. 20052006.26, Tab. 2). The predominance of grinders and millstones is also characteristic of the Luncavita site (Micu et al. 2005.235-236), which is contemporaneous with Carcaliu. These two types of tools are related to domestic activities, while the edge tools from Pericei are related to stone working, as most of the tools were left unfinished. At Hăbăşești (Iași county), a Cucuteni culture settlement, all the dwellings yielded two or three pieces, but they were usually fragmented (Dumitrescu 1954.250), which can be related to the long use of the tools, rather than primarily to their production, unlike at Pericei. The special situation of a house at Pietrele, a Gumelniţa culture site, deserves attention. Its inventory seems to have been complete (Klimscha 2011.Fig. 12), containing nine large flint axes, twelve small axes and five fragments. Again, the number of pieces found

\begin{tabular}{|c|c|c|c|c|c|c|c|c|c|c|c|c|c|}
\hline \multirow[b]{2}{*}{ Category } & \multirow[b]{2}{*}{ Type } & \multirow[b]{2}{*}{ Layer } & \multicolumn{9}{|c|}{ Dwellings } & \multicolumn{2}{|c|}{$\begin{array}{c}\text { Pebble } \\
\text { agglomerations }\end{array}$} \\
\hline & & & $\mathrm{L} 3$ & L6 & L7) & $\mathrm{C}_{1} / \mathrm{S}_{1}$ & $\mathrm{C}_{35} / \mathrm{S}_{11}$ & $\mathrm{C}_{48} 8 / \mathrm{S}_{13}$ & C68/S14 & $\mathrm{C}_{49 a / S_{15}}$ & $\mathrm{C}_{75} / \mathrm{S}_{19}$ & $\mathrm{C}_{30} \mathrm{OS} 13$ & $\mathrm{C}_{33 / \mathrm{S}_{11}}$ \\
\hline \multirow{2}{*}{ cores } & simple & 1 & & & & 1 & & & & & & & \\
\hline & worked & 1 & & & & & & & & & & & \\
\hline \multirow{3}{*}{ preforms } & chisel & 2 & & & & & & & 1 & & & & \\
\hline & ax-chisel & 1 & & & & & & & & & & & \\
\hline & unframed & 2 & & & & & & & & & & & \\
\hline \multirow{11}{*}{ chisels } & D1.in. & 2 & & & & & & & & & & & \\
\hline & Di.ad. & 1 & & & & & 1 & & & & & & \\
\hline & D2.in. & 1 & & & & & & & & & & & \\
\hline & D3.in. & 2 & & & & & 1 & & & & & & \\
\hline & D3.ad. & 2 & & & & & & & & & & & \\
\hline & $D_{3}$.fin. & & & & 1 & & & & & & & & \\
\hline & D4.in. & 1 & & & & & 1 & & & & & & \\
\hline & D4.ad. & & & & 1 & & & & & & & & \\
\hline & \begin{tabular}{l|} 
D4.fin. \\
\end{tabular} & 1 & & & & & & & & & & & \\
\hline & unframed.in & 2 & & & & & & 1 & & & & 1 & \\
\hline & fragments & 1 & & 1 & & 1 & & & & & & & \\
\hline \multirow{2}{*}{ axes } & T2.fin. & 1 & & & & & & & & & & & \\
\hline & fragments & 1 & & & & & & & 1 & & 1 & & \\
\hline ax-chisel & TD2 & 1 & & & & & & & & & & & \\
\hline \multirow{5}{*}{ adzes } & Te2.fin. & 1 & & & & & & & & & & & 1 \\
\hline & Te2.ad. & & & & & & & & & 1 & & & \\
\hline & Te3.fin. & & 1 & & & & & & & & & & \\
\hline & Te4.fin. & 1 & & & & & & & & & & & \\
\hline & Te4.in. & 1 & & & & & & & & & & & \\
\hline percutors & & 1 & & & & & & & & & & & \\
\hline millstones & & 3 & & & 1 & & & & & & & & \\
\hline waste & & 1 & & & & & & & 1 & & & & \\
\hline fragments & & 4 & & & 1 & & & & & & & & \\
\hline
\end{tabular}

Tab. 2. Context related to stone working (in. initial; ad. advanced; fin. finished). 

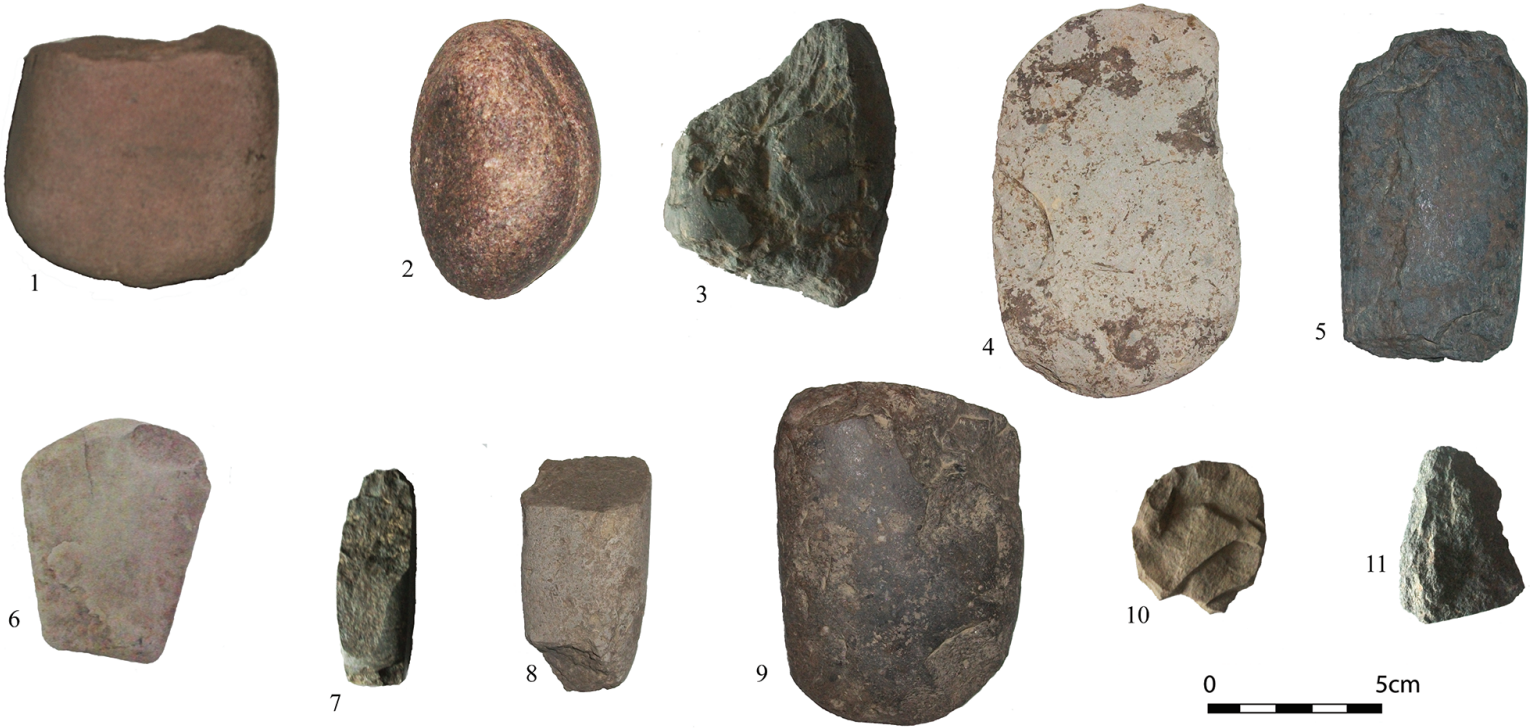

Fig. 12. Cores and preforms. 1 simple core; 2 core with fissure; 3 core with sawing marks; 4-6 chisel preforms; 7-8 undefined preforms; 9 axe-chisels preform; 10-11 waste.

there is much higher than in any dwelling at Pericei or even Ports, where the entire surface of some of the dwellings was investigated. The typology is also very different; neither the large nor the small flint axes have analogies at Pericei, and differences in function and operational chain are assumed (Klimscha 2011.368-369), but we presume that most tools were finished, unlike at Pericei.

Pebble agglomerations usually do not contain stones other than the raw one that defines them. The chisel in the initial stage of working from trench $\mathrm{C} 30 / \mathrm{S} 13$ might indicate the use of these structures for something other than just splitting pebbles. The division of ground stone working between outside and inside the house may be indicated by the placement of a pebble agglomeration next to a dwelling (Fig. 3.1).

In other contexts, three pits contained one item each, an adze or a chisel, all in the initial working stage. They show no signs of reject, failure of manufacture. An inhumation grave contained an adze of the Te1d type, and a ditch was the location of a chisel in the initial working stage.

\section{The characteristics of the ground stone in- dustry at Pericei}

The total number of pieces connected to this economic activity is not very large, but we must keep in mind the rather small area excavated at Pericei. The pebble agglomerations indicate

a local exploitation of stone resources, and most of the tools are unfinished. All the aforementioned facts provide sufficient grounds for proposing that
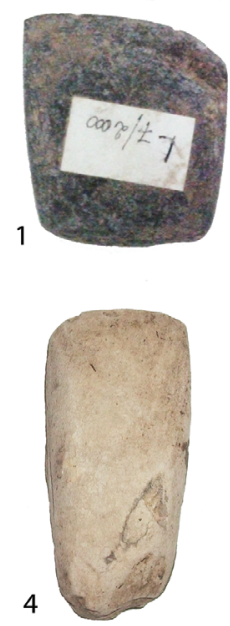

5

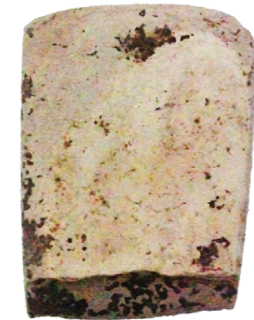

6

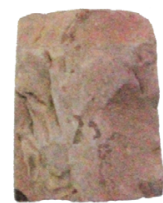

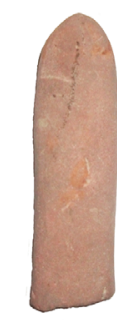

7

0

Fig. 13. Finished (1-3) and advanced working stage chisels (4-9). 1 type D3a; 2 type D3d; 3 type D4c; 4-6 type D1; 7 type D2; 8 type D3; 9 type D4. 
the settlement at Pericei was a centre for producing polished stone tools for trading, but we can add the relative standardisation of the lithic tools evident from the succession of techniques and similar approaches to working on most pieces.

The proximity of another settlement with the same economic orientation, namely at Port, raises questions regarding the relationship between them. We have seen that, culturally, they form part of the same group, the so-called Suplac group, and that they are partly contemporary, meaning that, in terms of the ground stone industry, the Port settlement begins production earlier and ends later. The principle products of the ground stone industry at Port were chisels and axes (at least in the Suplac II phase), while at Pericei the focus was on production of chisels. In this second phase, the demand for chisels increased and the industry at Pericei developed for that reason. That chisel production was mainly for trading purposes is indicated by the low proportion of finished pieces, with adzes being the most common in this category. The pre-
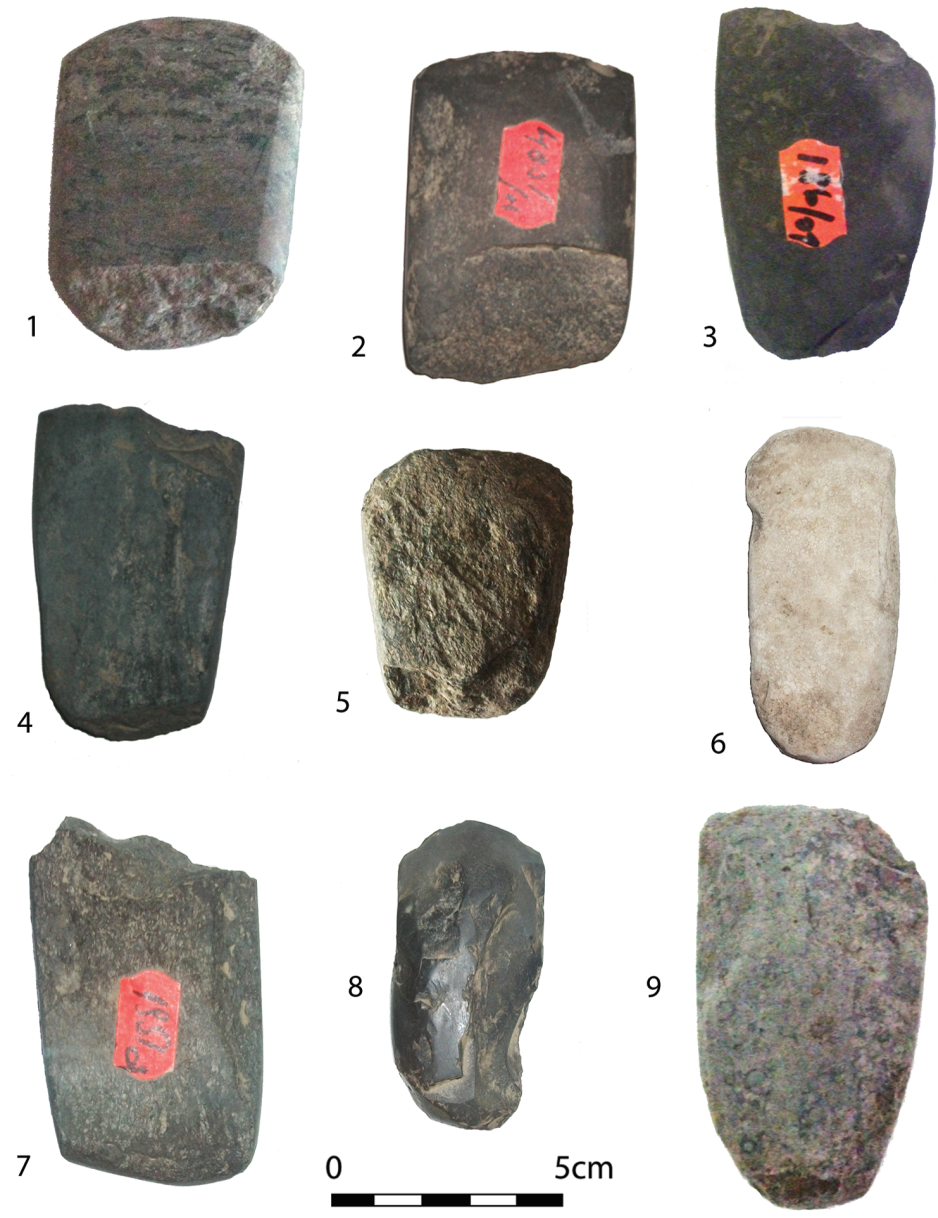

6

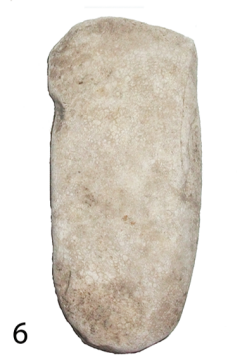

9

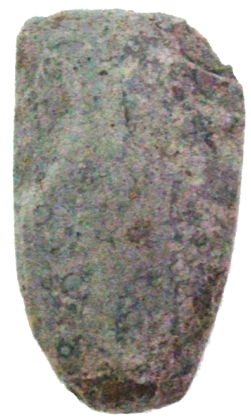

Fig. 14. Chisels in initial working stage. 1-2 type D1; 3-5 type D3; 6 type D4; 7-9 undefined.
1

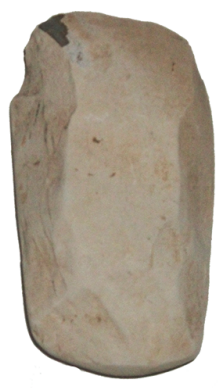

6

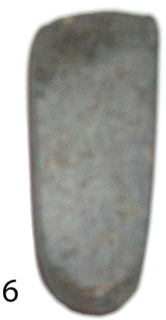

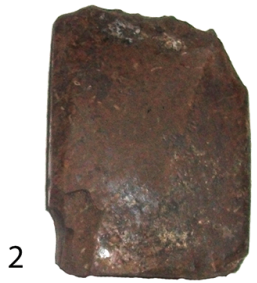

3

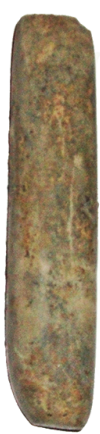

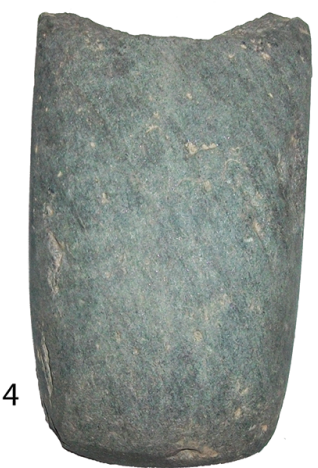

5

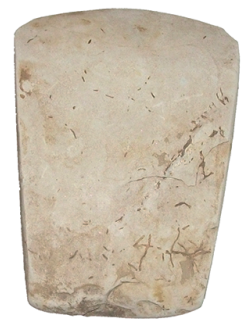

10

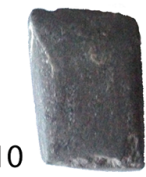

9

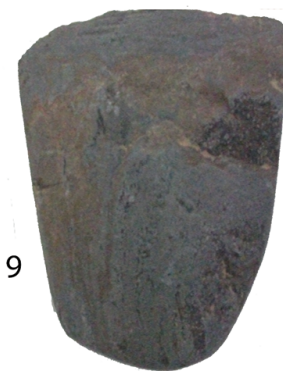

0 $5 \mathrm{~cm}$

Fig. 15. Chisels (1-2), axe (3), axe-chisel (4) and adzes (5-10). 1-2 in initial working stage (undefined); 3 axe type T2; 4 axe-chisel type TD2; 5 adze type Te1; 6-7 adze type Te2; 8-9 adze type Te3; 10 adze type Te4. 
ponderance of adzes is related to the scarcity of axes, and an increase in one category is correlated with a decrease in the other (Cotoi, Grasu 2000.5455). Adzes were versatile tools, able to function as an axe for some activities, such as the clearing of young trees (Barkai 2011.43). Only for this category we can make some observations regarding utilisation. Most of them are worn-out and have irregularities connected to retouching the edge or the faces.

At present, we cannot identify a settlement where chisels from Pericei arrived; future analysis of the lithic industry at Pericei and other sites will have to clarify this matter. Even for Suplac/ Porţ, only one site (i.e. Tăşad in Bihor county; Ignat 1987) has been identified as a recipient of its tools. We cannot say what the Neolithic inhabitants from Pericei received from other settlements. None of the chopped obsidian tools use local resources, as only finished items have been discovered (Băcuet Crişan 2008.37). Recent analysis indicates the region of Košice in Slovakia as a possible source of the obsidian tools found at Pericei and Port (Glascock et al. 2016. 85 ). It is probable that exchange networks existed

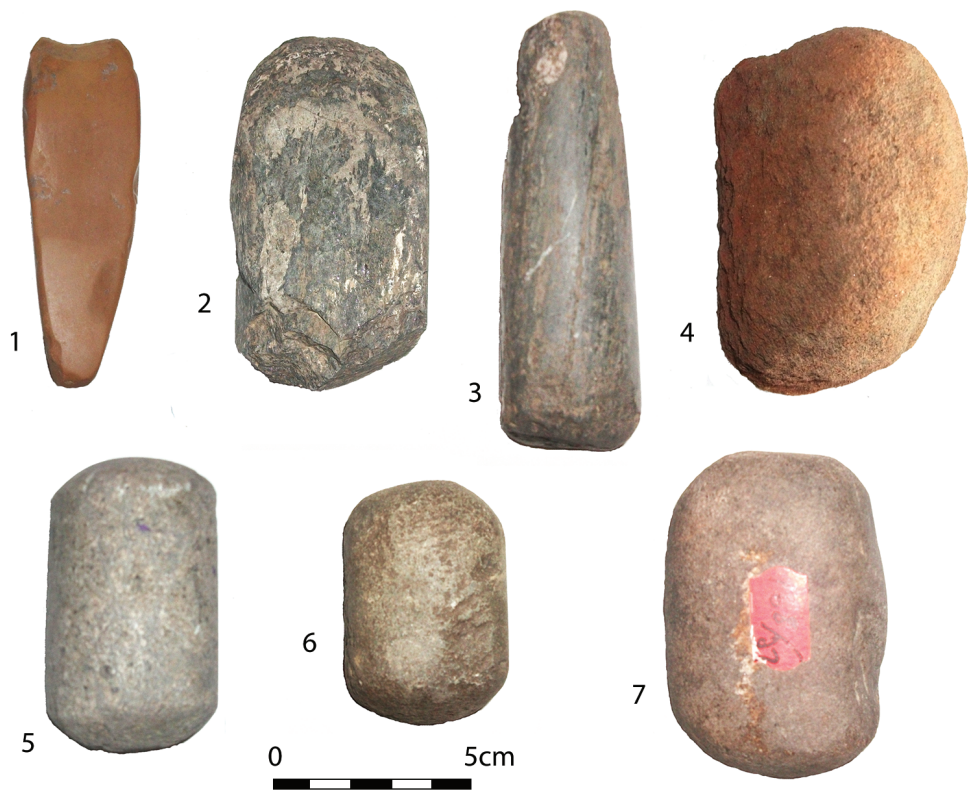

Fig. 16. Adzes (1-2), percutor, sandstone slab and millstones. 1 in advanced working stage, type Te2; 2 in initial working stage, type Te4; 3 percutor; 4 sandstone slab; 5-7 millstones. involving different objects over wide areas, as shown for stone axes produced in the alpine area (Pétrequin et al. 1997.139-140). Similar to that phenomenon, chisels from Pericei could have been traded unfinished, and the high proportion of initial and advanced stages of working may reflect not an accidental interruption of that process, but the expected shape(s) to be exchanged.

\section{References}

Barkai R. 2011. The evolution of Neolithic and Chalcolithic woodworking tools and the intensification of human production: axes, adzes and chisels from the Southern Levant. In V. Davis, M. Edmonds (eds.), Stone Axe Studies III. Oxbow Books. Oxford: 39-54.

Băcueţ Crişan S. 2007. Cluj-Cheile Turzii-Lumea Nouă. From general to particular-discoveries in the Simleu Depression. Studii de Preistorie 4: 67-85.

2008. Neoliticul şi eneoliticul timpuriu în Depresiunea Şimleului. Editura Altip. Alba-Iulia.

2013. Suplac, Zau, Pişcolt, Herpály...realitate sau probleme de interpretare? Acta Musei Porolissensis XXXV: $11-46$.

Băcueț Crişan S., Pop H. 2013. Aşezarea neolitică de la Şimleu Silvaniei - Str. T. Vladimirescu nr. 7 (II). Arheovest II. Interdisciplinaritate în arheologie şi Istorie: 33-50.
Băcueț Crişan S., Bejinariu I., Băcueț Crişan D., Culic D., and Pop H. 2011. Şantierul arheologic Porț "Corău". Cronica Cercetărilor Arheologice-campania 2010: 220-223.

2012. Şantierul arheologic Porț."Corău". Cronica Cercetărilor Arheologice-campania 2011: 245-246.

Băcueț Crişan S., Bejinariu I., Băcueț Crişan D., Culic D., Pop H., and Dunca M. 2013. Şantierul arheologic Porţ "COrău". Cronica Cercetărilor Arheologice-campania 2012: 173-174.

Cotoi 0., Grasu C. 2000. Uneltele din piatră şlefuită din eneoliticul Subcarpaților Moldovei. Editura Corson. Iaşi.

D'Amico C., Starnini E. 2011. Les "roches vertes alpines". Productions et circulations néolithiques en Italie septentrionale. In M. A. Borello (ed.), Les Hommes préhistoriques et les Alpes. Département de géographie et environnement de l'Université de Genève. Geneva: 125-134. 
2012. La production d'outils de pierre en Italie du Nord vue depuis l'atelier de Rivanazzano (province de Pavie, Lombardie): matières premières et chaîne opératoire. In P.-A. De Labriffe, É. Thirault (eds.), Produire des haches au néolithique. De la matière première à l'abandon. Société préhistorique française. Paris: 1523.

Dumitrescu H. 1954. Uneltele de producţie. In Hăbăşsşti. Monografie arheologică. Editura Academiei Republicii Populare Române. Bucureşti.

Dunca M. 2015. Etape ale prelucrării uneltelor din piatră şlefuită în situl de la Porţ-“Corău”. Acta Musei Porolissensis XXXVII: 39-51.

2016a. Clasificarea uneltelor din piatră şlefuită din situl de la Porţ-"Corău”. Analele Banatului S.N.: 87-105.

2016b. Organizarea prelucrării pietrei şlefuite la Porț"Corău". Ateliere? Acta Musei Porolissensis XXXVIII: 83-92.

Glascock M., Barker A., Băcueț Crişan S., Draşovean F., Gligor M., and Negrei D. 2016. Sourcing obsidian artifacts from archaeological sites in central and western Romania by x-ray fluorescence. Analele Banatului S.N.: 75-85.

Ignat D. 1987. Aşezarea neolitică de la Tăşad (jud. Bihor) aparţinând grupului Suplacu de Barcău. Crisia XVII: 9-17.

Ignat D. 1998. Grupul cultural neolitic Suplacu de Barcău. Editura Mirton. Timişoara.

Jeudi F., Jeunesse C., Monnier J. L., Pelegrin J., Pétrequin A.-M., Pétrequin P., and Praud I. 1995. Les carrières néolithiques de Plancher-les-Mines (Haute-Saône). Examples d'une approche intégrée. In J. Pelegrin, A. Richards (eds.), Les mines du silex au Néolithique en Europe: table ronde de Vesoul, 18-19 octobre 1991. Comité des Travaux Historiques et Scientifiques. Section de préhistoire et de protohistoire. Paris: 241-280.

Joye C. 2012. Hauterive Champréveyres (lac de Neuchâtel; Suisse). Les haches en pierre polie. Acquisition de la matière première et organisation spatiale, l'apport des déchets de fabrication. In P.-A. De Labriffe, É. Thirault (eds.), Produire des haches au néolithique. De la matière première à l'abandon. Société préhistorique française. Paris: $37-48$.

Klimscha F. 2011. Flint axes, ground stone axes and "battle axes" of the Copper Age in the Eastern Balkans (Romania, Bulgaria). In V. Davis, M. Edmonds (eds.), Stone Axe Studies III. Oxbow Books. Oxford: 361- 382.
Lazarovici C. M., Lazarovici Gh. 2006. Arhitectura neoliticului şi epocii cuprului din România. I. Neoliticul. Editura Trinitas. Iaşi.

Lazăr C., Ghergari L., and Ionescu C. 2007. Petrografia şi mineralogia unor unelte slefuite din situl neolitic de la Suplacu de Barcău. Nymphaea XXXIV: 5-37.

Matei A., Băcueț Crișan S., Bejinariu I., Pop H., Băcueț Crişan D., and Cârstea A. 2005. Santierul arheologic PericeiKeller Tag. Cronica Cercetărilor Arheologice din România-campania 2004: 259-262.

Micu C., Maille M., and Mihail F. 2005. Outils et pieces en pierre portant des traces de façonnage et/ou d' utilisation découverts à Luncaviţa (dép. de Tulcea). Cultură şi Civilizatie la Dunărea de Jos XXII: 223-239.

Micu C., Haita C-tin., and Mihail F. 2005-2006. Quelques observations sur les pieces en pierre polie découvertes dans l'etablissement eneolithique de Carcaliu (dép. de Tulcea). Peuce S.N.: 9-40.

Pétrequin A.-M., Pétrequin P. 2000. Des outils de pierre au XXe siècle. Magazine Documentaire BT 1120. Paris.

Pétrequin P., Cassen S., Croutsch C., and Weller 0. 1997. Haches alpins et carnaceénnes dans l'Europe du Ve millénaire. Notae Praehistoricae 17: 135-150.

Pétrequin P., Pétrequin A.-M., Errera M., Cassen S., and Croutsch C. 2006. Complexité technique et valorisation sociale: haches polies de Nouvelle-Guinée et du Néolithique alpin. In L. Astruc, F. Bon, V. Léa, P.-Y. Milcent, and S. Philibert (eds.), Normes techniques et pratiques sociales de la simplicité des outillages pré et protohistoriques, actes des XXVIe rencontres internationales d'archéologie et d'historie d'Antibes, 20-22 octobre 2005. Editions APDCA. Antibes: 419-433.

Pétrequin P., Bonetemps C., Buthod-Ruffier D., and Le Maux N. 2012. Approche expérimentale de la production des haches alpines. In P. Pétrequin, S. Cassen, M. Errera, L. Klassen, and A. Sheridan (eds.),Jade. Grandes haches alpines du Néolithique européen ve et IVe millénaires av. J.-C. Toulouse: 258-291.

Tsoraki C. 2007. Unravelling ground stone life histories: the spatial organisation of stone tools and human activities at LN Makriyalos, Greece. Documenta Praehistorica 34: 289-297. DOI: http://dx.doi.org/10.4312/dp.34.22

2011. Stone-working traditions in the prehistoric Aegean: The production of edge tools at Late Neolithic Makriyalos. In V. Davis, M. Edmonds (eds.), Stone Axe Studies III. Oxbow Books. Oxford: 231-244. 